\title{
Interactions of CCAAT/enhancer-binding protein $\beta$ with transcriptional coregulators
}

\begin{abstract}
CAAT/enhancer-binding proteins (C/EBPs) are key regulators of numerous cellular processes, including cell proliferation, differentiation, and tumorigenesis. Their biological activities require interactions with several protein partners and the formation of functional multiprotein complexes involved in DNA repair and cell cycle control. Members of the family (C/EBPa, $\beta, \delta, \varepsilon$, and $\gamma)$ bind to common DNA sequence motifs as homo- or hetero-dimers and interact with other transcription factors to control transcription of a number of eukaryotic genes. Of particular interest is C/EBP $\beta$, which binds to closed chromatin and acts as a pioneering factor for initiating tissue-specific gene expression at several promoters. This review focuses on intermolecular interactions that underlie C/EBP $\beta$ 's ability to regulate chromatin accessibility and directs readers to general reviews describing transcription regulation in eukaryotes.
\end{abstract}

\section{INTRODUCTION}

Transcriptional machinery access to the core promoter region is restricted in eukaryotic cells by the dense packing of chromatin. The barrier imposed by compacted chromatin is overcome by the concerted action of sequence-specific DNA-binding transcription factors (TFs), which stimulate transcription of their target genes by regulating the assembly and/or activity of transcriptional initiation complexes. They elicit their effect by recruiting members of a diverse family of coactivators that modify chromatin structure and mediate recruitment of the RNA polymerase II complex (Pol II) to the transcriptional start site. Local chromatin opening at several specific genomic regions is often triggered by a special class of TFs, known as pioneer TFs, which are able to associate with closed chromatin and pave the way for the binding of other factors. For example, CCAAT/enhancer-binding protein beta $(\mathrm{C} / \mathrm{EBP} \beta)$ acts as a pioneering factor for adipogenetic TFs [1] facilitates recruitment of the glucocorticoid receptor to steroid response elements [2], and triggers the initial steps of chromatin opening at the mim-1 enhancer, facilitating Myb binding to the promoter [3].

The basic unit of chromatin, the nucleosome, is composed of 146 DNA base pairs wrapped around an octamer of the four core histones. The accessibility of the DNA template is modulated by two major classes of chromatin-modifying enzymes: chromatin-remodeling complexes that utilize ATP hydrolysis to alter the histone-DNA contacts in the nucleosome and those that covalently modify histone proteins, such as histone acetyltransferase (HAT) and deacetylase (HDAC) complexes, histone methyltransferases (HMTs), and histone kinases. Acetylation and phosphorylation change the net charge of the nucleosome, thereby facilitating chromatin unraveling and histone displacement from DNA. The second function of histone modifications is the recruitment of nonhistone proteins carrying the enzymatic activities necessary to further modify chromatin and/or establish enhancer-promoter communication. For example, acetylated lysine residues are recognized by bromodomains present in several chromatin modifiers themselves and also in the components of TFIID [4]. Activator recruitment of HATs and HMTs is crucial for the activation of many classes of genes, whereas deacetylation of the histone tails is required for repression. Histone lysine methylation is involved in both gene activation and repression, depending on the specific lysine residue that gets modified, as well as on its degree of methylation $[5,6]$.

Activation is a complex, cooperative process that involves the dynamic rearrangement of contacts between TFs, various coactivators, and chromatin-remodeling factors, and requires highly specific, yet weak, readily reversible interactions. Recent live-cell experiments have demonstrated that the av-

\section{Maria Miller}

Protein Structure Section, Macromolecular Crystallography Laboratory, National Cancer Institute at Frederick, Frederick, USA

Protein Structure Section, Macromolecular Crystallography Laboratory, National Cancer Institute at Frederick, Frederick, MD, 21702 1201, USA; phone: (301) 846-5342, fax: (301) 846-6128, e-mail: mariami@mail.nih.gov

Received: June 2, 2016

Accepted: June 29, 2016

Key words: transcription, $\mathrm{C} / \mathrm{EBP} \beta$, chromatin remodeling, chromatin-modifying complexes

Abbreviations: bZIP - basic region leucine zipper; C/EBP - CCAAT/enhancer-binding protein; DAXX - death domain-associated protein; HAT - histone acetyltransferase; HDAC - histone deacetylase; HMT - histone methyltransferase; ISWI - imitation SWItch; PTIP - Pax transactivation domain-interacting protein; SWI/SNF - SWItch/sucrose nonfermentable TF - transcription factor; TAD - transactivation domain

Acknowledgements: The author thanks Dr. P.F. Johnson for many useful suggestions and thoughtful comments on the manuscript. This work was supported by the Intramural Research Program of the National Institutes of Health, National Cancer Institute, Center for Cancer Research. 

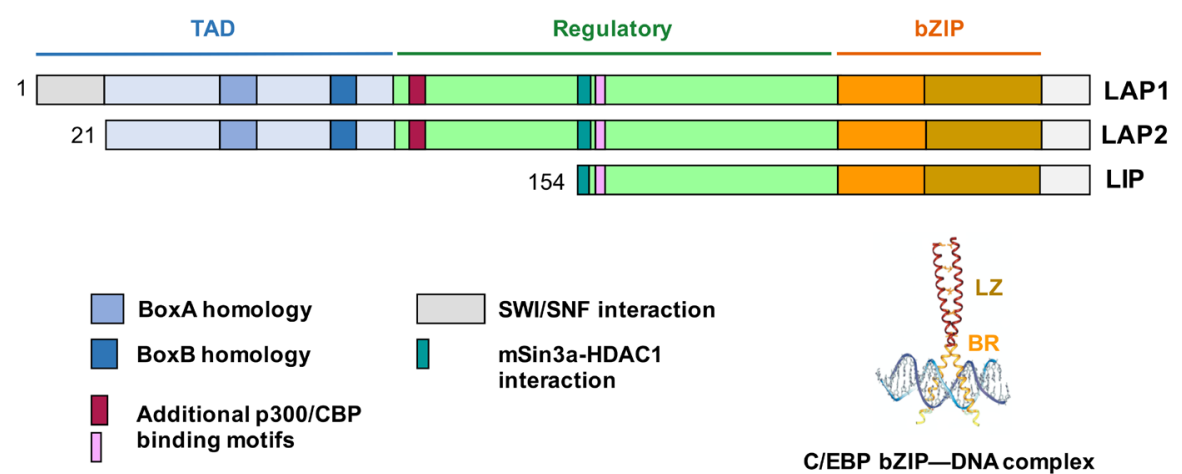

LAP2 LIP

Figure 1. Domain organization of $\mathrm{C} / \mathrm{EBP} \beta$ and protein interaction motifs.

$\mathrm{C} / \mathrm{EBP} \beta$ is expressed as three isoforms with distinct activities: fulllength LAP1, LAP2 lacking 21 amino acids (23 in human proteins) from the $\mathrm{N}$-terminus, and LIP, which lacks the whole activation domain (TAD) and acts as a transcriptional repressor. The difference within 21/23 amino acids between LAP1 and LAP2 leads to functional differences between the two isoforms due to different patterns of post-translational modifications and protein interactions, as well as a changed network of disulfide bonds maintaining the latent forms of the proteins [11]. LAP1 participates in terminal differentiation, whereas

erage time of interactions between TFs and chromatin is measured in seconds [7]. Depending on the cell type and external stimulus, distinct sets of regulatory proteins can assemble at the same promoter. The possibility of interacting with distinct coregulator complexes underlies the capability of certain TFs to perform tissue- and cell typedependent dual functions. For example, C/EBP proteins, which interact with the general coactivator, CBP/p300, and usually act as transcriptional activators, were shown to inhibit PPAR $\beta$ gene expression in mouse keratinocytes through the recruitment of a transcriptional repressor complex containing HDAC1 [8].

\section{C/EBP $\beta$ : STRUCTURAL AND FUNCTIONAL DOMAINS}

C/EBPs (C/EBPa, $\beta, \delta, \varepsilon$, and $\gamma)$ are modular proteins consisting of an $\mathrm{N}$-terminal transactivation domain (TAD), central regulatory regions, and a highly conserved C-terminal basic region leucine zipper (bZIP) domain required for DNA binding (Fig. 1). The N-terminal parts of C/EBPs exhibit little overall sequence homology, except for two segments termed homology box I and homology box II that are embedded in the common acidic TADs [9]. Several sequence motifs specific for $C / E B P \beta$ and conserved among specimens are shown in figure 1 . The bZIP domain binds to palindromic DNA sequences as a dimer of uninterrupted helices, with each basic region contacting a half-site in the major groove. The helical fold of the basic region is induced upon binding to its cognate DNA site. The simplicity of this protein-DNA recognition motif, together with the structural flexibility of the basic region, may explain $\mathrm{C} / \mathrm{EBP} \beta^{\prime}$ s ability to bind directly to nucleosomal DNA [10].
A
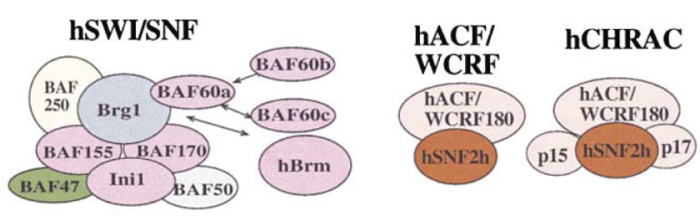

B

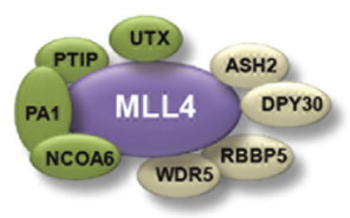

Figure 2. Chromatin-modifying complexes. (A) Human ATP-dependent remodeling complexes of SWI/SNF and ISWI families (modified from [34]). (B) Human Set-1 like MLL4 H3K4 methyltransferase complex. Core subunits that are common with other mammalian H3K4 methylases are shown in white, and unique subunits: PTIP, PA1, NCOA6, and UTX, are shown in green (modified from [31]).
LAP2 and LIP promote cell proliferation and tumor progression. The proper ratios of all three isoforms are critical for normal growth and development.

\section{C/EBP $\beta$ RECRUITS SWI/SNF AND ISWI CHROMATIN REMODELERS}

ATP-dependent chromatin-remodeling enzymes comprise a large family of protein complexes divided into four subfamilies, SWI/SNF, ISWI, INO80, and CHD, which display specialized biological functions imparted by their protein components and unique domain compositions [12]. All members of the family use the energy of ATP hydrolysis to alter the packaging state of the chromatin structure, which changes the accessibility of nucleosomal DNA to cognate TFs. The changes may include transient unwrapping of the end of DNA from histone octamers, forming a DNA loop or sliding nucleosomes to different positions. The SWI/SNF remodelers participate in both gene activation and repression, whereas the ISWI subfamily complexes (such as ACF, CHRAC, and ATRX), which are able to assemble chromatin from histones and DNA, have been mainly linked to gene silencing and repression. Repression of genes that are required for pluripotency in differentiating cells is necessary for maintaining cellular identity.

Mammalian SWI/SNF is composed of a heterogeneous mixture of subunits that contain BRG1 or hBrm as a central catalytic subunit and a varying number of BRG1-associated factors (BAFs) (Fig. 2A). The SWI/SNF complex is recruited to chromatin-embedded silent genes by the LAP1 isoform to control terminal differentiation in several cell lines [13]. Neither LAP2 nor the R3L-mutant protein was able to perform this function. It has been demonstrated that the intact, 21-residue N-terminal is necessary for maintaining direct interactions with the BRG1/hBrm and BAF47 subunits of the SWI/SNF complex. However, the isolated peptide (residues 1-21), as well as other TAD fragments, showed only weak 
affinity for $\mathrm{hBrm}$, suggesting that full-length $\mathrm{C} / \mathrm{EBP} \beta$ TAD participates in binding to SWI/SNF. On the other hand, all three isoforms were found to interact with human SNF2H, ACF, and ACF1, which are components of ACF- and CHRAC-remodeling complexes belonging to the ISWI family (Fig. 2A). Thus, the differential roles in transcription regulation played by $C / E B P \beta$ isoforms in the same cellular context can be, in part, explained by differences in their associations with the chromatin-remodeling complexes [14].

\section{THE INTERPLAY BETWEEN ACETYLATION AND DEACETYLATION}

HATs, CBP, and CBP's paralogue, p300, play critical roles in the regulation of chromatin structure and may activate gene expression by connecting the enhancer-bound TFs with basal transcriptional machinery at promoters [15]. Apart from the domains necessary for catalytic activity, p300 and CBP share highly conserved domains for protein-ligand binding. Through these protein-interacting domains, p300/CBP mediates the assembly of multiprotein transcriptional complexes, which, in addition to a variety of TFs, include signaling molecules, nuclear hormone receptors, and additional HATs [16].

Although their major targets are histone 3 lysine 18 (H3K18) and histone 3 lysine 27 (H3K27), CBP/p300 and $\mathrm{CBP} / \mathrm{p} 300$-associated GCN5 also acetylate several TFs, including $\mathrm{C} / \mathrm{EBP} \beta$, altering their transactivation potential [17]. Reciprocally, the HAT activities of p300 and CBP coactivators are modulated by the phosphorylation induced by specific kinases associated with certain p300/ CBP-bound TFs [18]. The binding of C/EBP activators to $\mathrm{CBP} / \mathrm{p} 300$ results in the phosphorylation of multiple Ser/Thr-Pro sites in the C-terminal region of p300/CBP [19], and in acetylation of C/EBP $\beta$ at lysines $39,98,101$, and 102 [17]. The interdependence between $C / E B P \beta$-induced p300 phosphorylation and p300-mediated C/EBP $\beta$ acetylation provides an efficient control of transcriptional responses to cellular signaling [20].

The reversal of histone acetylation by HDAC proteins counteracts the effects of HATs by returning the histone to its basal state, and it also correlates with transcriptional repression. HDACs can regulate gene repression via nonhistone substrates. HDACs are divided into three major families. Class I and II enzymes depend on the zinc ion for their catalytic activity, whereas class III consists of NAD-dependent enzymes of the Sir family [21] [6]. HDAC enzymes are usually components of larger, multiprotein repressive chromatin complexes. The interaction of C/EBP $\beta$ with HDAC deacetylases is mediated by corepressor mSin3a [22]. C/EBP $\beta$ 's association with the $\mathrm{mSi}$ n3a-HDAC1 complex leads to the repressed transcription of many genes, including C/EBPa [22] and PPAR $\beta$ [8], as well as p53, sirtuin 1, and GSK3 $\beta$ [23]. The interaction requires an AAGF sequence motif located at the $\mathrm{N}$-terminus of the LIP isoform (Fig. 1). All three isoforms interact readily with the $\mathrm{mSin} 3$ a corepressor, however, the binding of LAP1/LAP2 to the mSin3a-HDAC complex may be diminished by $\mathrm{p} 300$-induced $\mathrm{C} / \mathrm{EBP} \beta$ acetylation (see above) at lysines K98, K101 and K102, therefore only LIP actively inhibits $C / E B P \beta$-dependent transcription through HDAC1. In fact, glucocorticoid stimulation displaces HDCA1 from LAP1/LAP2 and activates preadipocyte differentiation [24]. Reversible acetylation mediated by $\mathrm{p} 300$ and HDAC1 also regulates the promoter activity of interleukin-12 [25].

\section{THE STRUCTURAL BASIS OF C/EBP'S INTERACTIONS WITH p300}

The Taz2 domain of CBP/p300 binds specifically to acidic TADs of several TFs, including the p53 tumor suppressor, ETF2, and members of the STAT and C/EBP families. The structure of the Taz2 domain consists of a bundle of four a-helices linked by three zinc fingers. The peptide-binding surface is formed by residues from the hydrophobic core that maintain a rigid arrangement of four helices [26]. C/EBP activators bind to the Taz2 domain of CBP/p300 through their minimal TADs, which comprise both conserved homology boxes A and B [19].

Interactions between $\mathrm{C} / \mathrm{EBP} \varepsilon$ and the p300 Taz2 domain were revealed by X-ray crystallography at $1.5 \AA$ resolution [27] (Fig. 3). The intramolecular interface involves 19 residues from the C/EBPE TAD and extends over $757.5 \AA^{2}$. The hydrophobic interactions are supplemented by nine hydrogen bonds and one salt bridge. The bound $\mathrm{C} / \mathrm{EBP} \varepsilon \mathrm{TAD}$ peptide (residues 37 to 58 ) forms the L-letter structure composed of two helices separated by a three-residue linker (Fig. 3A). The N-terminal helix, which corresponds to the homology box A, interacts with residues from Taz2 helices a 3 and a4, and also contacts Thr1776 from the Znf2 loop. In addition to the hydrophobic interactions involving Ile42, Tyr45, and Ile46, the side chain of Asp41 makes polar contacts with both the side chain and the main chain $\mathrm{NH}$ of Thr1775 from the Znf2 loop, as well as with the main chain NH from Asn1776. Residues 48-51 do not make contact with Taz2. The homology box B helix (residues 51-59) binds, through its hydrophobic face (Leu53, Leu54, Leu57, and Phe58), to the large hydrophobic surface at the interface between helices a 1 and a 3 (Fig. 3), and contributes more than $60 \%$ of the total buried surface area and van der Waals contacts. In addition, Asp56 forms a salt bridge with Lys1783.

The bipartite binding of C/EBPE to Taz2 suggests that other members of the family may interact with Taz2 in a similar manner, via two highly conserved amphipathic helical motifs connected by flexible linkers. The ability of $C / E B P \beta$ alone to induce local chromatin opening suggests its strong association with coactivators. Accordingly, C/EBP $\beta$ interactions with p300 or CBP involve additional sequence motifs, GYVSLGRA and LRAYL (Fig. 1), which are located in the region C-terminal to TAD [28]. The position of the bound C/EBPE (37-61) peptide C-terminus in the complex with Taz2 indicates that the additional $C / E B P \beta$ region could bind to a large hydrophobic surface of Taz2, which is known as a binding site for the p53 N-terminal TAD and the E1A oncoprotein (Fig. 4). In contrast, the $\mathrm{N}$ terminus of $\mathrm{C} / \mathrm{EBP} \varepsilon$ peptide is oriented toward the opposite side of the Taz2 surface, which is 

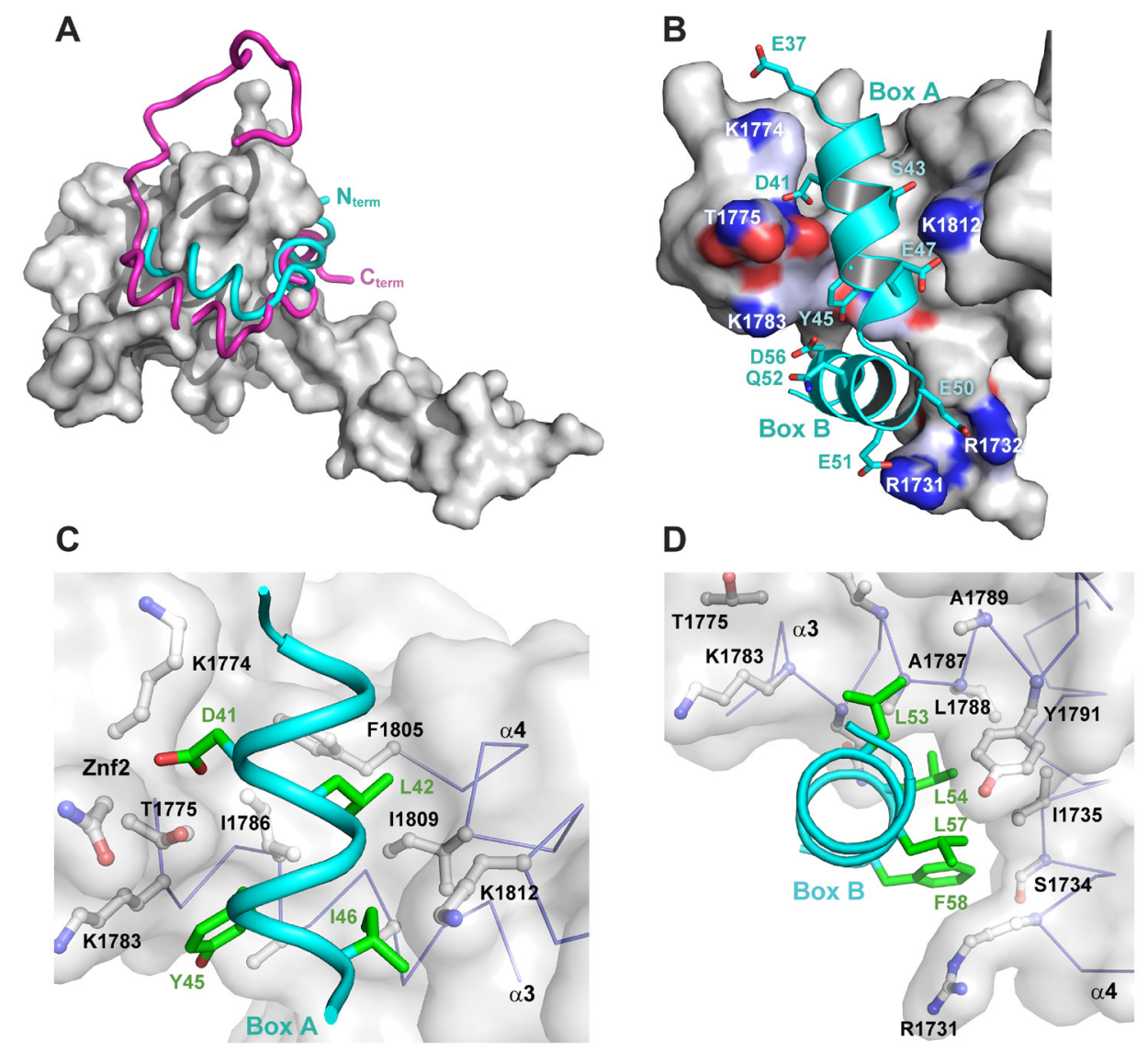

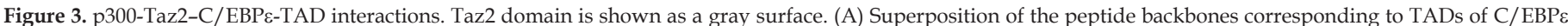

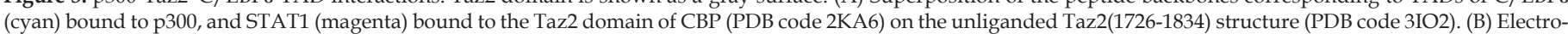

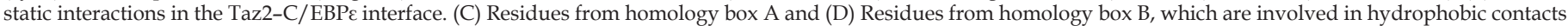
with Taz2 surface. Originally published in [27].

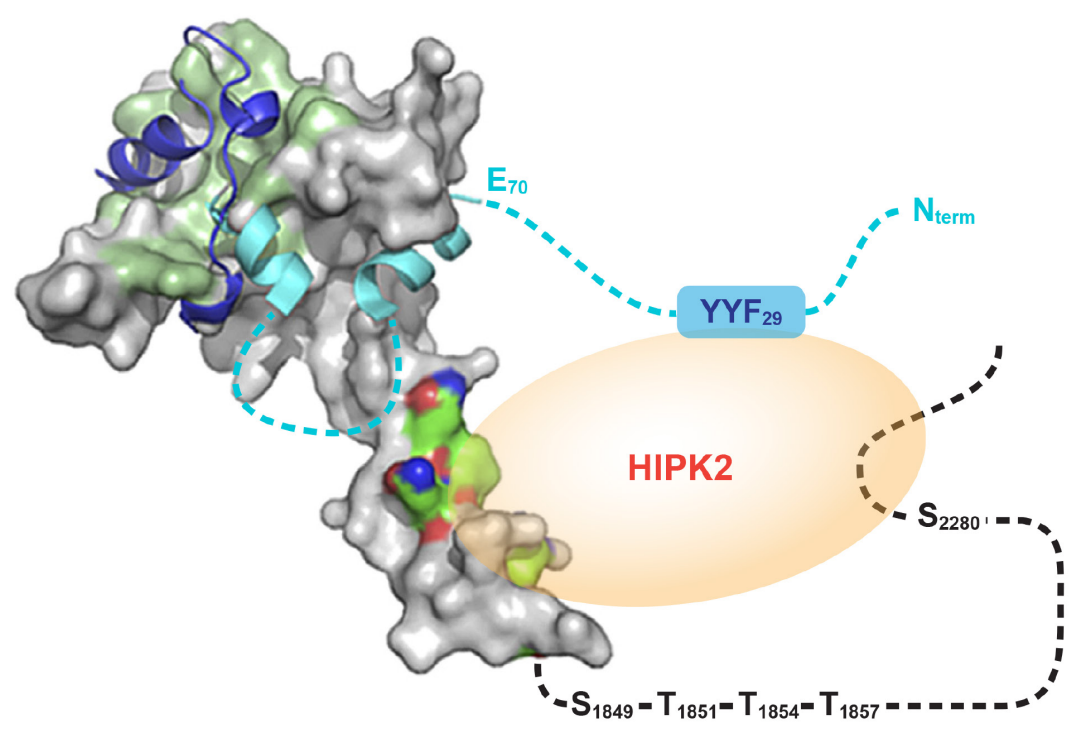

Figure 4. A hypothetical model of the Taz2-C/EBP $\beta-H I P K 2$ ternary complex. The structure (PDB code 3IO2) of the p300 Taz2 domain (residues 1726-1834) is shown as a gray surface. Residues comprising the binding site for p53 and E1A are colored light green. The bound E1A chain (PDB code 2KJE) is shown as navy blue ribbon. Homology boxes $\mathrm{A}$ and $\mathrm{B}$ from $\mathrm{C} / \mathrm{EBP} \beta$ are shown as cyan ribbon. Regions predicted to be disordered (C/EBP $\beta \mathrm{N}$ terminus and the linker connecting the two homology boxes, as well as the p300 region following Taz2 a4), are marked as dashed lines. The HIPK2 docking site is shown as a blue box. Originally published in [27]. devoid of features required for specific binding, suggesting that segments of $\mathrm{C} /$ EBPs N-terminal to homology box A are unbound in the C/EBP-p300-Taz2 complexes. This observation is in agreement with the known location of the docking site of protein kinase HIPK2 on the C/ $\mathrm{EBP} \beta \mathrm{N}$ terminus, which associates with the C/EBP $\beta$-p300 complex [20]. A possible spatial arrangement of $C / E B P \beta$, Taz2, and HIPK2 in a stable ternary complex is shown in figure 4 .

\section{DAXX REPRESSES C/EBP $\beta$ ACTIVITY IN AN HDAC-INDEPENDENT MANNER}

The transcriptional activity of $\mathrm{C} /$ $E B P \beta$ is also negatively regulated by death domain-associated protein (DAXX) [29]. DAXX is a multi-domain scaffold protein that plays diverse roles in cellular processes. Its best characterized role is that of a transcriptional corepressor. DAXX interacts with CBP/ p300, HDACs, ATRX, and a number of TFs. It directly binds to C/EBP $\beta$ and decreases both $C / E B P \beta$-dependent phos- 
phorylation of p300 and p300-induced acetylation of C/ EBP $\beta$. The DAXX-C/EBP $\beta$ interactions were mapped to the central helical domain of DAXX and the C-terminal bZIP domain of C/EBP $\beta$. Interestingly, DAXX represses $\mathrm{C} / \mathrm{EBP} \beta$ transcriptional activity in an HDAC-independent manner by a mechanism that is currently unknown.

\section{C/EBP $\beta$ REQUIRES MLL4 METHYLTRANSFERASE FOR ENHANCER ACTIVATION DURING ADIPOGENESIS}

Covalent histone modifications play important roles in regulating gene expression and cell differentiation. Histone lysine methylation is dynamically regulated by specific methyltransferases and demethylases. Histone H3 lysine 4 (H3K4) methylation is associated with gene activation, whereas histone $\mathrm{H} 3$ lysine 27 (H3K27) methylation prevents $\mathrm{H} 3 \mathrm{~K} 27$ acetylation and correlates with gene repression. Genome-wide analyses revealed that established enhancers are marked by mono- and di-methylation of histone 3 lysine 4 (H3K4me1/2), whereas moieties tri-methylated at histone 3 lysine 4 (H3K4me3) are predominantly present at active promoters [30]. Establishing active enhancers to bind lineage-determining TFs at cell type-specific genomic regions is particularly important during differentiation. Mono- and di-methylation at H3K4 in mammals is implemented mainly by MLL4 (also known as KMT2D) methyltransferase, with some MLL3 redundancy. MLL3 and MLL4 are catalytic subunits of the Set1-like MLL3/MLL4 H3K4 methyltransferase complex, which, in addition to containing common core subunits of other mammalian H3K4 methylases, contains unique subunits: PTIP and associated PA1, NCOA6, and H3K27-specific demethylase, UTX (Fig. 3B). Pax transactivation domain-interacting protein (PTIP) mediates the complex assembly and also links its components to enhancer-bound TFs and various coactivators [31]. Physical interactions of C/EBP $\beta$ with the MLL3/MLL4 complex were confirmed by immunoprecipitation experiments $[32,33]$.

Members of the C/EBP family cooperate with PPARy to control differentiation of fat cell precursors, preadipocytes, into mature adipocytes (adipogenesis). C/EBP $\beta$ regulates chromatin-remodeling events during the early stage of differentiation, activates expression of PPARY and $\mathrm{C} / \mathrm{EBP} \alpha$, and facilitates cooperative binding of other adipogenic TFs to specific genomic regions [1]. Step-wise, differentiation-stage enhancer activation by $\mathrm{C} / \mathrm{EBP} \beta$ critically depends on MLL4 activity. C/EBP $\beta$ binds to closed chromatin in preadipocytes and recruits the MLL4 complex to PPARY and C/EBPa gene loci to initiate local chromatin opening prior to the induction of PPARY expression. After PPARY and $\mathrm{C} / \mathrm{EBP} \alpha$ are expressed, they cooperatively de novo recruit MLL4 first, and then p300, to complete enhancer activation by H3K27 acetylation [33]. The H3K4me1 mark on enhancers usually precedes the H3K27ac mark on active enhancer and correlates with loss of H3K27me3. The MLL4 complex is required for C/ EBP $\beta$-dependent H3K27 acetylation by p300, which suggest involvement of demethylase UTX.

\section{PERSPECTIVE}

Regulation of transcription in eukaryotes depends on the dynamic association of multiprotein complexes with cis-regulatory elements. C/EBP $\beta$ regulates activities of several cell-type and cell-state specific enhancers through interactions with chromatin modifying complexes. Chromatin modifications promote enhancer accessibility to specific transcription factors, contribute to the combinatorial assembly of transcriptional complexes, and modulate longrange communication with promoters. In this respect, it is apparent from the examples described above that the three translational isoforms of $\mathrm{C} / \mathrm{EBP} \beta$ play differential roles in transcription and may also have distinct physiological roles. Thus, C/EBP $\beta$ might elicit completely opposite effects on cell proliferation depending on the cell-type and C/EBP $\beta$ isoform present. LAP1 is believed to regulate terminal differentiation processes, whereas LAP2 and LIP are involved in cell proliferation and tumor progression in a number of tissues. To understand the molecular mechanisms underlying the diverse functions of these isoforms, future studies should be directed toward identifying their molecular partners. An equally important line of investigation is to determine the cellular cues that affect the expression levels of the three isoforms and to explain how the isoform ratio controls cell proliferation.

\section{REFERENCES}

1. Siersbaek R, Nielsen R, John S, Sung MH, Baek S, Loft A, Hager GL, Mandrup S (2011) Extensive chromatin remodelling and establishment of transcription factor ,hotspots' during early adipogenesis. EMBO J 30: 1459-1472

2. Grontved L, John S, Baek S, Liu Y, Buckley JR, Vinson C, Aguilera G, Hager GL (2013) C/EBP maintains chromatin accessibility in liver and facilitates glucocorticoid receptor recruitment to steroid response elements. EMBO J 32: 1568-1583

3. Plachetka A, Chayka O, Wilczek C, Melnik S, Bonifer C, Klempnaue $\mathrm{KH}(2008) \mathrm{C} /$ EBPbeta induces chromatin opening at a cell-type-specific enhancer. Mol Cell Biol 28: 2102-2112

4. Filippakopoulos P, Knapp S (2012) The bromodomain interaction module. FEBS Lett 586: 2692-2704

5. Li B, Carey M, Workman JL (2007) The role of chromatin during transcription. Cell 128: 707-719

6. Kouzarides T (2007) Chromatin modifications and their function. Cell 128: 693-705.

7. Stavreva DA, Varticovski L, Hager GL (2012) Complex dynamics of transcription regulation. Biochim Biophys Acta 1819: 657-666

8. Di-Poi N, Desvergne B, Michalik L, Wahli W (2005) Transcriptional repression of peroxisome proliferator-activated receptor beta/delta in murine keratinocytes by CCAAT/enhancer-binding proteins. J Biol Chem 280: 38700-38710

9. Ramji DP, Foka P (2002) CCAAT/enhancer-binding proteins: structure, function and regulation. Biochem J 365: 561-575

10. Miller M (2009) The importance of being flexible: the case of basic region leucine zipper transcriptional regulators. Curr Protein Pept Sci 10: $244-269$

11. Zahnow C (2009) CCAAT/enhancer-binding protein beta: its role in breast cancer and associations with receptor tyrosine kinases. Expert Rev Mol Med 11: e12

12. Clapier CR, Cairns BR (2009) The biology of chromatin remodeling complexes. Annu Rev Biochem 78: 273-304

13. Kowenz-Leutz E, Leutz A (1999) A C/EBP beta isoform recruits the SWI/SNF complex to activate myeloid genes. Mol Cell 4: 735-743 
14. Steinberg XP, Hepp M I, Fernandez Garcia Y, Suganuma T, Swanson S K, Washburn M, Workman JL, Gutierrez JL (2012) Human CCAAT/ enhancer-binding protein beta interacts with chromatin remodeling complexes of the imitation switch subfamily. Biochemistry 51: $952-962$

15. McManus KJ, Hendzel MJ (2001) CBP, a transcriptional coactivator and acetyltransferase. Biochem Cell Biol 79: 253-266

16. Goodman RH, Smolik S (2000) CBP/p300 in cell growth, transformation, and development. Genes Dev 14: 1553-1577

17. Cesena TI, Cardinaux JR, Kwok R, Schwartz J (2007) CCAAT/enhancer-binding protein $(\mathrm{C} / \mathrm{EBP})$ beta is acetylated at multiple lysines: acetylation of C/EBPbeta at lysine 39 modulates its ability to activate transcription. J Biol Chem 282: 956-967

18. Aikawa Y, Nguyen L A, Isono K, Takakura N, Tagata Y, Schmitz ML, Koseki H, Kitabayashi I (2006) Roles of HIPK1 and HIPK2 in AML1 and p300-dependent transcription, hematopoiesis and blood vessel formation. EMBO J 25: 3955-3965

19. Kovacs KA, Steinmann M, Magistretti PJ, Halfon O, Cardinaux JR (2003) CCAAT/enhancer-binding protein family members recruit the coactivator CREB-binding protein and trigger its phosphorylation. J Biol Chem 278: 36959-36965

20. Steinmann S, Coulibaly A, Ohnheiser J, Jakobs A, Klempnauer KH (2013) Interaction and cooperation of the CCAAT-box enhancer-binding protein beta (C/EBPbeta) with the homeodomain-interacting protein kinase 2 (Hipk2). J Biol Chem. 288: 22257-22269

21. Chen HP, Zhao YT, Zhao TC (2015) Histone deacetylases and mechanisms of regulation of gene expression. Crit Rev Oncog 20: 35-47

22. Abdou HS, Atlas E, Hache RJ (2013) A positive regulatory domain in CCAAT/enhancer binding protein beta (C/EBPBeta) is required for the glucocorticoid-mediated displacement of histone deacetylase 1 (HDAC1) from the C/ebpalpha promoter and maximum adipogenesis. Endocrinology 154: 1454-1464

23. Jin J, Iakova P, Jiang Y, Lewis K, Sullivan E, Jawanmardi N, Donehower L, Timchenko L, Timchenko NA (2013) Transcriptional and translational regulation of C/EBPbeta-HDAC1 protein complexes controls different levels of p53, SIRT1, and PGC1alpha proteins at the early and late stages of liver cancer. J Biol Chem 288: 14451-14462
24. Wiper-Bergeron N, Salem HA, Tomlinson JJ, Wu D, Hache RJ (2007) Glucocorticoid-stimulated preadipocyte differentiation is mediated through acetylation of C/EBPbeta by GCN5. Proc Natl Acad Sci USA 104: 2703-2708

25. Lu J, Sun H, Wang X, Liu C, Xu X, Li F, Huang B (2005) Interleukin-12 p40 promoter activity is regulated by the reversible acetylation mediated by HDAC1 and p300. Cytokine 31: 46-51

26. Miller M, Dauter Z, Cherry S, Tropea JE, Wlodawer A (2009) Structure of the Taz2 domain of p300: insights into ligand binding. Acta Crystallogr D65: 1301-1308

27. Bhaumik P, Davis J, Tropea JE, Cherry S, Johnson PF, Miller M (2014) Structural insights into interactions of C/EBP transcriptional activators with the Taz2 domain of p300. Acta Crystallogr D70: 1914-1921

28. Lee S, Miller M, Shuman JD, Johnson PF (2010) CCAAT/enhancer binding protein $B$ DNA binding is auto-inhibited by multiple elements that also mediate association with p300/CBP. J Biol Chem 285: 2139921410

29. Wethkamp N, Klempnauer KH (2009) Daxx is a transcriptional repressor of CCAAT/enhancer-binding protein beta. J Biol Chem 284: 28783-28794

30. Calo E, Wysocka J (2013) Modification of enhancer chromatin: what, how, and why? Mol Cell 49: 825-837

31. Hu D, Gao X, Morgan MA, Herz HM, Smith ER, Shilatifard A (2013) The MLL3/MLL4 branches of the COMPASS family function as major histone H3K4 monomethylases at enhancers. Mol Cell Biol 33: 47454754

32. Cho YW, Hong S, Jin Q, Wang L, Lee JE, Gavrilova O, Ge K (2009) Histone methylation regulator PTIP is required for PPARgamma and C/ EBPalpha expression and adipogenesis. Cell Metab 10: 27-39

33. Lee JE, Wang C, Xu S, Cho YW, Wang L, Feng X, Baldridge A, Sartorelli V, Zhuang L, Peng W, Ge K (2013) H3K4 mono- and di-methyltransferase MLL4 is required for enhancer activation during cell differentiation. Elife 2: $\mathrm{e} 01503$

34. Narlikar GJ, Fan HY, Kingston RE (2002) Cooperation between complexes that regulate chromatin structure and transcription. Cell 108 $475-487$

\section{Oddziaływania pomiędzy białkiem $\beta$ wiążącym sekwencję wzmacniającą CCAAT a regulatorami transkrypcyjnymi Maria Miller $\bowtie$}

Protein Structure Section, Macromolecular Crystallography Laboratory, National Cancer Institute at Frederick, Frederick, MD, 21702-1201, USA e-mail: mariami@mail.nih.gov

Słowa kluczowe: transkrypcja, C/EBP $\beta$, remodeling chromatyny, kompleksy modyfikujące chromatynę

\section{STRESZCZENIE}

Białka wiążące sekwencję wzmacniającą (enhancer) CCAAT (C/EBPs) odgrywają kluczową rolę w licznych procesach komórkowych, w tym w proliferacji komórek, różnicowaniu i kancerogenezie. Ich aktywność biologiczna wymaga oddziaływania z wieloma partnerami i tworzenia funkcjonalnych - złożonych z szeregu białek - kompleksów, które biorą udział w naprawie DNA i w kontroli cyklu komórkowego. Przedstawiciele rodziny białek C/EBP (C/EBPa, $\beta, \delta, \varepsilon, \gamma)$ wiążą się z tą samą sekwencją DNA jako homo- lub heterodimery i kontrolują transkrypcję szeregu genów eukariotycznych. Szczególnie interesujące jest białko C/EBP $\beta$, które przyłącza się do zamkniętej chromatyny i, torując drogę innym czynnikom, umożliwia rozpoczęcie ekspresji genów specyficznych dla wielu tkanek. Niniejsza praca koncentruje się na opisie oddziaływań międzycząsteczkowych umożliwiających zmianę struktury chromatyny poprzez C/EBP $\beta$ oraz kieruje czytelników do artykułów przeglądowych opisujących regulację transkrypcjii u Eucaryota. 